Doi: HTTPS://DOI.ORG/10.23910/IJBSM/2018.9.2.1849b

\title{
Effect of Various Post Harvest Treatments on Storage Behaviour of Aonla cv. Chakaiya
}

\author{
Rocky Thokchom* and Goutam Mandal
}

Dept. of Horticulture \& Post-Harvest Technology, Institute of Agriculture, Visva-Bharati, Sriniketan, West Bengal (731 236), India

\section{Corresponding Author}

Rocky Thokchom

e-mail: rockythokchom@rocketmail.com

\author{
Article History \\ Article ID: AR1849b \\ Received in $05^{\text {th }}$ October, 2017 \\ Received in revised form $17^{\text {th }}$ December, 2017 \\ Accepted in final form $19^{\text {th }}$ March, 2018
}

\begin{abstract}
The present laboratory investigation was aiming to assess the influence of various post-harvest treatments on storage behaviour of aonla fruits during the year 2015-16 in the 'Department of Horticulture and Post-Harvest Technology, Institute of Agriculture, Visva-Bharati, Sriniketan'. Freshly harvested physiological mature fruits of aonla cv. Chakaiya of uniform size, shape, colour, free from disease and bruises were given various post-harvest treatment of gibberellic acid (GA $: 50$ ppm, 100 ppm), naphthalene acetic acid (NAA: 20 ppm, 30 ppm) and calcium chloride $\left(\mathrm{CaCl}_{2}: 1,1.5 \%\right)$ and were air dried and kept in 5 ply corrugated boxes (5\% ventilations) with newspaper lining and stored in room temperature. The fruits were analysed for various quality attributes at different storage intervals up to 12 days. The results revealed that physiological loss in weight $(4.94,7.06$ and $9.04 \%)$ and spoilage percent $(0,0$ and $15 \%)$ of the fruits remain minimum after 4,8 and 12 days respectively in $\mathrm{CaCl}_{2}(1 \%)$ treated fruits during storage. Whereas, TSS $\left(9.28,10.82\right.$ and $\left.12.46^{\circ} \mathrm{B}\right)$, acidity $(2.31,2.08$ and

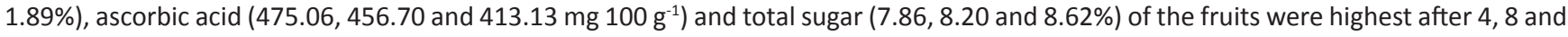
12 days respectively in $\mathrm{GA}_{3}(100 \mathrm{ppm})$ treated fruits during storage. This study shows that the storability and quality of aonla fruits can be favourably influenced during storage when treated with calcium chloride and $\mathrm{GA}_{3}$.
\end{abstract}

Keywords: Aonla, $\mathrm{GA}_{3}, \mathrm{NAA}, \mathrm{CaCl}_{2}$, storage, post-harvest quality

\section{Introduction}

Aonla (Emblica officinalis Gaertn.) also known as 'Indian Gooseberry' is native to tropical south-east Asia (Jain and Khurdiya, 2004). It is a small sized, minor subtropical fruit belongs to the family Euphorbiaceae, having immense potential for cultivation on marginal or wastelands. It thrives well throughout tropical and subtropical India and is widely cultivated in the region extending from the base of Himalaya to Ceylon and Malaysia to south China. India ranks first in area (0.1 mha) and production (1.2 $\mathrm{mt}$ ) of aonla in the world (Anonymous, 2014). Aonla cultivation is more common in northern India particularly in Uttar Pradesh (Bajpai and Shukla, 2002) and is spreading fast in drier parts of the country viz. Andhra Pradesh, Rajasthan, Haryana, Gujarat, Madhya Pradesh etc. (Anonymous, 2014). In West Bengal aonla cultivation are confined in Purulia, Bankura, Birbhum, West Midnapore (Singh, 2012). Nutritional, commercial and medicinal significance of aonla fruit makes it popular all over the world (Goyal et al., 2007). It is a rich source of vitamin C and its content of ascorbic acid is next to only that of Barbados cherry (Malpighia glabra L.) (Chadha, 2002) and it is the main ingredient of traditional 'Ayurvedic medicine' (Pathak, 2001;
Singh et al., 2008). It is also an excellent source of amino acid and minerals along with phytochemicals (Jain and Khurdiya, 2004; Murthy and Joshi, 2007; Baliga and Dsouza, 2011). Fruits are sour and astringent in taste and are occasionally eaten raw or processed. It is much esteemed for making pickles, preserves, jellies, supari, candy, churan and blended beverages of aonla juice with lime and ginger (Tandon et al., 2003). Chakaiya is a seedling selection having tall upright growth habit. It bears profusely and is regular bearer. Fruit is small to medium, flattened, smooth skin, greenish in colour. Flesh is fibrous and hard. It is a late maturing variety suitable for pickles and other products. The fruit is highly perishable in nature and it is available for a short period. Its storage life in atmospheric conditions after harvesting is only 5-6 days (Pathak et al., 2009). Therefore, it needs immediate marketing and utilization. To have good return to avoid market glut it becomes essential to store the fruits for a considerable period. Appropriate post harvest treatment, storage and processing methods can curtail the post-harvest losses to 30\% (Goyal et al., 2008) and make the fruit available for longer (Singh et al., 2009). Dip treatment in plant growth regulators like GA, NAA and calcium compound chemicals $\left(\mathrm{CaCl}_{2}\right)$ play a great part for short period storage of various fruits (Ahmead et al., 2005; 
Kahlon and Uppal, 2005; Singh et al., 2008; Gangwar et al., 2012; Kumar et al., 2014). Thus, to overcome the post-harvest losses, the present investigation was undertaken to study the effect of post- harvest treatments on storage behaviour and quality of aonla cv. Chakaiya.

\section{Materials and Methods}

\subsection{Site of study}

The present investigation was carried out in post-harvest laboratory of 'Department of Horticulture and Post-Harvest technology, Institute of Agriculture, Visva-Bharati, Sriniketan' during 2015 to 2016 . The experimental region is located at an elevation of $40 \mathrm{~m}$ above mean sea level at $23^{\circ} 42^{\prime} \mathrm{N}$ latitude and $87^{\circ} 47^{\prime} 30^{\prime \prime}$ E longitudes, representing humid sub-tropical region under 'Red lateritic' region of West Bengal.

\subsection{Treatments and methods of analysis}

Fresh fruits of uniform size, shape and colour of aonla cv. Chakaiya free from disease and bruises were harvested at the physiological mature stage during the morning hours and brought to the laboratory. The fruits were dipped treated in aqueous solution of different concentration of $\mathrm{GA}_{3}$ (50 and $100 \mathrm{ppm}$ ), NAA (20 and $30 \mathrm{ppm}$ ) and $\mathrm{CaCl}_{2}$ (1 and 1.5\%) each for 5 minutes. The fruits were air dried and packed in 5 ply corrugated boxes ( $5 \%$ ventilations) with newspaper lining and stored in room temperature. A control lot of fruit (kept in 5 ply corrugated box without any treatment) was also stored in same condition. Observations were taken at an intervals of 4 days up to 12 days. The cumulative physiological loss in weight (PLW) of the fruit was determined on the basis of initial weight of the fruit and how much loss in weight occurred and was expressed in percent. Spoilage percent were recorded by visual observation. The spoilage of fruits was assayed by counting the numbers of fruits get spoiled and/ or display fungal mycelia or sporulation and were expressed as percent of total number of fruits. The total soluble solid (TSS) content of fruits was determined with the help of an Erma Hand Refractometer, Japan and expressed in per cent after making the temperature correction at $20^{\circ} \mathrm{C}$. The ascorbic acid and acidity were estimated by the method described by AOAC (2000).

\subsection{Statistical analysis}

The experiment was carried out in completely randomized block design and each treatment was replicated thrice. The data were analysed as per the method of Panse and Sukhatme (1985). Least significant difference at 5\% levels was used for finding the significant differences among the treatment means.

\section{Results and Discussion}

\subsection{Physical traits (PLW and Spoilage \%)}

Physiological loss in weight (PLW) generally increased as
Table 1: Physical characteristics (PLW and spoilage) of aonla fruits (cv. Chakaiya) in relation to various post-harvest treatments on storage period

\begin{tabular}{|c|c|c|c|c|c|c|c|c|}
\hline \multirow[t]{3}{*}{ Treatments } & \multicolumn{4}{|c|}{ PLW (\%) } & \multicolumn{4}{|c|}{ Spoilage (\%) } \\
\hline & \multicolumn{8}{|c|}{ Storage period (days) } \\
\hline & 0 & 4 & 8 & 12 & 0 & 4 & 8 & 12 \\
\hline Control & 0 & 6.61 & 8.80 & 11.05 & 0 & 5 & 15 & 30 \\
\hline $\mathrm{GA}_{3} 50 \mathrm{ppm}$ & 0 & 5.64 & 7.84 & 9.82 & 0 & 0 & 10 & 20 \\
\hline $\mathrm{GA}_{3} 100 \mathrm{ppm}$ & 0 & 5.13 & 7.26 & 9.28 & 0 & 0 & 5 & 15 \\
\hline NAA 20 ppm & 0 & 5.85 & 8.04 & 10.12 & 0 & 0 & 10 & 25 \\
\hline NAA 30 ppm & 0 & 6.17 & 8.35 & 10.34 & 0 & 0 & 10 & 30 \\
\hline $\mathrm{CaCl}_{2} 1 \%$ & 0 & 4.94 & 7.06 & 9.04 & 0 & 0 & 0 & 15 \\
\hline $\mathrm{CaCl}_{2} 1.5$ & 0 & 5.78 & 7.92 & 9.92 & 0 & 0 & 5 & 20 \\
\hline SEm \pm & 0 & 0.02 & 0.01 & 0.02 & 0 & 0 & 0.38 & 0.66 \\
\hline $\mathrm{CD}(p=0.05)$ & 0 & 0.07 & 0.03 & 0.06 & 0 & 0 & 1.16 & 2.01 \\
\hline
\end{tabular}

the storage period advanced, rather slowly initially but more rapidly as perusal of data in Table 1 . This finding is in conformity with the finding of Mandal et al. (2012) who reported gradual increasing in weight loss with increase in storage period in guava. The data in Table 1 revealed that PLW of the fruits remain minimum (4.94, 7.06 and 9.04\%) after 4,8 and 12 days respectively for storage in $\mathrm{CaCl}_{2}(1 \%)$ treated, followed by $\mathrm{GA}_{3}(100 \mathrm{ppm})$ treated within the stipulated storage period of 12 days, whereas maximum PLW (6.61, 8.80 and $11.05 \%$ ) was observed in control fruits after 4, 8 and 12 days respectively. These observations are in accordance with the studies of Gupta and Singh (2016) which reported the lowest PLW in aonla with the application of $1 \%$ calcium chloride+0.1\% Bavistin and Tarula et al. (2015) which reported favourable effects of $\mathrm{CaCl}_{2}(1 \%)$ in reducing PLW in NA-10 aonla.

The spoilage of aonla fruit started much earlier in untreated fruits from $4^{\text {th }}$ days onwards whereas among the treated fruit spoilage started from $8^{\text {th }}$ days onward. Results from Table 1 shows maximum spoilage percent $(5,15$ and $30 \%)$ in control treatment fruits in 4, 8 and 12 days' interval respectively whereas minimum spoilage percent $(0,0$ and $15 \%)$ was observed in $\mathrm{CaCl}_{2}(1 \%)$ treated followed by $\mathrm{GA}_{3}$ (100 ppm) treated fruits. All the treatments reduced spoilage percent as compared to control. The current study demonstrates that the application of $\mathrm{CaCl}_{2}$ has merit in reducing spoilage in aonla fruits which may be due to their positive role in delaying the senescence of fruits by maintaining cell wall integrity and thus lowering the spoilage. Earlier workers (Tarula et al., 2015; Gupta and Singh, 2016) also reported that the application of $\mathrm{CaCl}_{2}$ was found most effective in minimising the spoilage in aonla. Gangwar et al. (2012) also reported significant reduction in pathological loss and increase shelf life of aonla 
fruits up to 15 days by application of $1 \%$ calcium nitrate.

\subsection{Chemical quality attributes (TSS, titratable acidity and ascorbic acid)}

From the results in Table 2 it is evident that total soluble solids (TSS) increased with the increase in the duration of storage irrespective of treatments and the treatments are significantly differed from one another. Increased TSS in treated fruits might be attributed to the breakdown of starch into sugars or the hydrolysis of cell wall polysaccharides (Crouch, 2003) or to the enzymatic conversion of higher polysaccharides such as starch and pectin into simple sugars during ripening (Hussain et al., 2008). The control treatment recorded lowest TSS (8.73, 9.72 and $10.8^{\circ} \mathrm{B}$ ) whereas the maximum TSS content (9.28, 10.82 and $\left.12.46^{\circ} \mathrm{B}\right)$ was recorded in $\mathrm{GA}_{3}(100 \mathrm{ppm})$ treated fruits in 4,8 and 12 days' interval respectively. These results are in conformity with the finding of Tarula et al. (2015) who reported maximum TSS content in aonla NA-7 and NA-10 fruits treated with $\mathrm{GA}_{3} 100 \mathrm{ppm}$. Similarly, it was previously determined that post-harvest $\mathrm{GA}_{3}$ treatments increased the TSS content in Banana (Duguma et al., 2014; Archana and
Sivachandiran, 2015).

The acidity of aonla fruits experiences a linear decline during the storage period (Table 2). The rapid decrease in acidity under prolonged storage might be due to rapid utilization of organic acid during respiration (Albertini et al., 2006). However, the loss of acidity during storage was more rapid and faster in control and NAA treated fruits, but it was gradual in $\mathrm{GA}_{3}$ and $\mathrm{CaCl}_{2}$ treated fruits. The lowest acidity $(2.11,1.85$ and $1.56 \%$ ) was noticed in the control treatment whereas the highest acidity $(2.31,2.08$ and $1.89 \%)$ was observed in $\mathrm{GA}_{3^{\prime}}$ (100 ppm) treated in 4, 8 and 12 days' interval respectively. These findings are more are less similar to those observed by Tarula et al. (2015) who reported minimum malic acid content in cv. Chakaiya fruits treated with $\mathrm{GA}_{3}$ (300 ppm). Similar results were obtained by Harman and Sen (2016) from the studies of $\mathrm{GA}_{3}(100 \mathrm{ppm})$ treatment on 'Obilnaja' and 'Black Star' cultivars of plum.

The continuous decrease of ascorbic acid content with the advancement of storage period was observed in all the treatments. The decrease in ascorbic acid content on

Table 2: Chemical quality attributes (TSS, titratable acidity and ascorbic acid) of aonla fruits (cv. Chakaiya) in relation to various post-harvest treatments on storage period

\begin{tabular}{|c|c|c|c|c|c|c|c|c|c|}
\hline \multirow[t]{3}{*}{ Treatments } & \multicolumn{3}{|c|}{$\begin{array}{c}\operatorname{TSS}\left({ }^{\circ} \mathrm{B}\right) \\
\text { initial value (0 Day): } 7.83^{\circ} \mathrm{B}\end{array}$} & \multirow{2}{*}{\multicolumn{3}{|c|}{$\begin{array}{c}\text { Acidity (\%) } \\
\text { initial value (0 Day): } 2.50 \% \\
\text { Storage period (days) }\end{array}$}} & \multicolumn{3}{|c|}{ 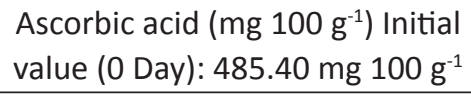 } \\
\hline & \multirow[b]{2}{*}{4} & \multirow[b]{2}{*}{8} & \multirow[b]{2}{*}{12} & & & & & & \\
\hline & & & & 4 & 8 & 12 & 4 & 8 & 12 \\
\hline Control & 8.73 & 9.72 & 10.81 & 2.11 & 1.85 & 1.56 & 455.36 & 440.24 & 389.73 \\
\hline $\mathrm{GA}_{3} 50 \mathrm{ppm}$ & 9.2 & 10.66 & 12.22 & 2.26 & 1.98 & 1.72 & 473.63 & 451.17 & 409.19 \\
\hline $\mathrm{GA}_{3} 100 \mathrm{ppm}$ & 9.28 & 10.82 & 12.46 & 2.31 & 2.08 & 1.89 & 475.06 & 456.70 & 413.13 \\
\hline NAA 20 ppm & 8.79 & 9.84 & 10.99 & 2.08 & 1.77 & 1.48 & 467.29 & 455.54 & 400.04 \\
\hline NAA 30 ppm & 8.81 & 9.88 & 11.05 & 2.03 & 1.60 & 1.38 & 463.35 & 442.67 & 396.67 \\
\hline $\mathrm{CaCl}_{2} 1 \%$ & 9.08 & 10.42 & 11.86 & 2.17 & 1.90 & 1.67 & 461.87 & 439.71 & 394.79 \\
\hline $\mathrm{CaCl}_{2} 1.5$ & 8.93 & 10.12 & 11.41 & 2.29 & 2.00 & 1.75 & 471.19 & 450.22 & 406.16 \\
\hline SEm \pm & 0.03 & 0.12 & 0.02 & 0.02 & 0.01 & 0.01 & 4.31 & 3.88 & 4.80 \\
\hline $\mathrm{CD}(p=0.05)$ & 0.10 & 0.37 & 0.05 & 0.05 & 0.04 & 0.03 & 13.09 & 11.77 & 14.55 \\
\hline
\end{tabular}

prolonged storage might be due to the oxidation of ascorbic acid to dehydroascorbic acid as reported by Mazurek and Pankiewiez (2012). The decrease in ascorbic acid was significantly more in untreated fruits than the chemically treated fruits. The highest ascorbic acid content (476.06,

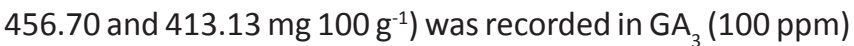
treated and the lowest $(455.36,440.24$ and $389.73 \mathrm{mg} 100$ $\mathrm{g}^{-1}$ ) in control treatment fruits in 4,8 and 12 days' interval respectively (Table 2 ). The finding is in conformity with the finding of Dhumal et al. (2008) recorded maximum ascorbic acid content in fruits treated with $6 \%$ waxol $+100 \mathrm{ppm} \mathrm{GA}_{3}$.

3.3. Chemical quality attributes (Reducing sugar, non-reducing sugar and total sugar)

The maximum content of reducing sugar $(2.25,2.33$ and 2.52 $\%)$, non-reducing sugar $(5.61,5.87$ and $6.10 \%)$ and total sugar $(7.86,8.20$ and $8.62 \%)$ in 12 days' storage were observed in $\mathrm{GA}_{3^{\prime}},(100 \mathrm{ppm})$ treated fruits in 4,8 and 12 days' interval respectively (Table 3 ). The increase in sugar content in fruits during post-harvest storage depends upon respiration rate and a complex series of enzymatically controlled biochemical reaction such as a conversion of starch. Earlier workers have reported that the application of $\mathrm{GA}_{3}$ showed slight increase in total sugar contents during storage period in Banana (Duguma et al., 2014) and in plum (Harman and Sen, 2016). 
Table 3: Chemical quality attributes (Reducing sugar, non-reducing sugar and total sugar) of aonla fruits (cv. Chakaiya) in relation to various post-harvest treatments on storage period

\begin{tabular}{|c|c|c|c|c|c|c|c|c|c|}
\hline \multirow[t]{3}{*}{ Treatments } & \multicolumn{3}{|c|}{$\begin{array}{l}\text { Reducing sugar (\%) } \\
\text { initial value (0 Day): } 2.10 \%\end{array}$} & \multirow{2}{*}{\multicolumn{3}{|c|}{$\begin{array}{l}\text { Non-reducing sugar (\%) } \\
\text { initial value (0 Day): } 5.35 \% \\
\text { Storage period (days) }\end{array}$}} & \multicolumn{3}{|c|}{$\begin{array}{c}\text { Total sugar (\%) } \\
\text { initial value (0 Day): } 7.45 \%\end{array}$} \\
\hline & \multirow[b]{2}{*}{4} & \multirow[b]{2}{*}{8} & \multirow[b]{2}{*}{12} & & & & & & \\
\hline & & & & 4 & 8 & 12 & 4 & 8 & 12 \\
\hline Control & 2.18 & 2.24 & 2.33 & 5.44 & 5.67 & 5.88 & 7.62 & 7.91 & 8.21 \\
\hline $\mathrm{GA}_{3} 50 \mathrm{ppm}$ & 2.24 & 2.33 & 2.49 & 5.57 & 5.83 & 6.02 & 7.81 & 8.16 & 8.51 \\
\hline $\mathrm{GA}_{3} 100 \mathrm{ppm}$ & 2.25 & 2.33 & 2.52 & 5.61 & 5.87 & 6.10 & 7.86 & 8.20 & 8.62 \\
\hline NAA 20 ppm & 2.14 & 2.26 & 2.35 & 5.40 & 5.60 & 5.85 & 7.54 & 7.86 & 8.20 \\
\hline NAA 30 ppm & 2.19 & 2.28 & 2.38 & 5.48 & 5.71 & 5.91 & 7.67 & 7.99 & 8.29 \\
\hline $\mathrm{CaCl}_{2} 1 \%$ & 2.20 & 2.30 & 2.41 & 5.50 & 5.75 & 5.95 & 7.70 & 8.05 & 8.36 \\
\hline $\mathrm{CaCl}_{2} 1.5$ & 2.22 & 2.31 & 2.44 & 5.53 & 5.77 & 5.97 & 7.75 & 8.08 & 8.41 \\
\hline SEm \pm & 0.02 & 0.01 & 0.02 & 0.01 & 0.01 & 0.02 & 0.02 & 0.02 & 0.03 \\
\hline $\mathrm{CD}(p=0.05)$ & 0.05 & 0.03 & 0.05 & 0.04 & 0.04 & 0.05 & 0.06 & 0.07 & 0.09 \\
\hline
\end{tabular}

\section{Conclusion}

Shelf life of aonla goes on decreasing with the prolong days of storage. $\mathrm{GA}_{3}(100 \mathrm{ppm})$ treatment was found to be effective in retaining the quality of aonla fruits while $\mathrm{CaCl}_{2}$ at $1 \%$ was found to be effective in minimising the pathological loss and post-harvest losses in weight of fruits in aonla cultivars studied.

\section{References}

Ahmead, M.S., Thakur, K.S., Kaushal, B.B.L., 2005. Post harvest treatments to retain kinnow storage quality. Indian Journal of Horticulture 62(1), 63-67.

Albertini, M.V., Carcouet, E., Pailly, O., Gambotti, C., Luro, F., Berti, L., 2006. Changes in organic acids and sugars during early stages of development of acidic and acidless citrus fruit. Journal of Agricultural and Food Chemistry 54, 8335-39.

Anonymous., 2014. Area and production of different fruits in India. National Horticulture Board, India. www.nhb. gov.in

AOAC., 2000. Official Methods of Analysis, edn 17. Association of Official Analytical Chemists, Washington DC.

Archana, U., Sivachandiran, S., 2015. Effect of application of gibberellic acid $\left(\mathrm{GA}_{3}\right)$ on shelf-life of banana. International Journal of Research in Agriculture and Food Sciences 3, 2311-476.

Bajpai, P.N., Shukla, H.S., 2002. Aonla. In: Fruits: tropical and subtropical. Vol II, Naya Udyog, 206 Bidhan Sarani, Calcutta, West Bengal, India, 527-528.

Baliga, M.S., Dsouza, J.J., 2011. Amla (Emblica officinalis Garten), a wonder berry in the treatment and prevention of cancer. European Journal of Cancer Prevention 20, 225-239.

Chadha, K.L., 2002. Hand book of horticulture. ICAR, New
Delhi, India.

Crouch, I., 2003. 1-Methylcyclopropene (Smartfresh TM) as an alternative to modified atmosphere and controlled atmosphere storage of apples and pears. Acta Horticulture 600, 433-36.

Dhumal, S.S., Karale, A.R., Garande, V.K., Patil, B.T., Masalkar, S.D., Kshirsagar, D.B., 2008. Shelf life of aonla fruits: influenced by post-harvest treatments and packaging materials. Indian Journal of Agricultural Research 42(3), 189-194.

Duguma, T., Egigu, M.C., Muthuswamy, M., 2014. The effects of gibberellic acid on quality and shelf life of banana (Musa spp.). International Journal of Current Research and Review 6 (23), 66-69.

Gangwar, S., Shukla, H.S., Katiyar, D., Pandey, V., 2012. Effect of calcium nitrate on physico-chemical changes and shelf-life of aonla (Emblica officinalis Gaertn.) fruits. HortFlora Research Spectrum 1(3), 253-258.

Goyal, R.K., Kingsly, A.R.P., Kumar, P., Walia, H., 2007. Physical and mechanical properties of Aonla fruits. Journal of Food Engineering 82, 595-599.

Goyal, R.K., Patil, R.T., Kinglsly, A.R.P., Walia, H., Kumar, P., 2008. Status of post harvest technology of Aonla in India - A Review. American Journal of Food Technology 3, 13-23.

Gupta, N., Singh, V.B., 2016. Pre-harvest foliar application of calcium chloride, bavistin and bayleton on post-harvest life of Emblica officinalis Gaertn. fruits. Bangladesh Journal of Botany 45(1), 211-219.

Harman,Y., Sen, F., 2016. The effect of different concentrations of pre-harvest gibberellic acid on the quality and durability of 'Obilnaja' and 'Black Star' plum varieties. Food Science and Technology (Campinas) 36(2), 362368.

Hussain, I., Zeb, A., Shakir, I., Shah, A.S., 2008. Combined 
effect of potassium sorbate and sodium benzoate on individual and blended juices of apricot and apple fruits grown in Azad Jammu and Kashmir. Pakistan Journal of Nutrition 7, 181-85.

Jain, S.K., Khurdiya, D.S., 2004. Vitamin C enrichment of fruit juice based ready-to-serve beverages through blending of Indian gooseberry (Emblica officinalis Gaertn.) juice. Plant Foods for Human Nutrition 59, 63-66.

Kahlon, P.S., Uppal, R.S., 2005. Effect of post harvest treatment on shelf life of mango cv. Chausa. Haryana Journal of Horticultural Sciences 34(1-2), 51-53.

Kumar, R., Lal, S., Kumar, M., 2014. Effect of post harvest packing materials and calcium on shelf life of guava. Agricultural Research Journal 34(2), 127-130.

Mandal, G., Dhaliwal, H.S., Mahajan, B.V.C., 2012. Effect of pre-harvest application of NAA and potassium nitrate on storage quality of winter guava (Psidium guajava). Indian Journal of Agricultural Sciences 82 (11), 985-9.

Mazurek, A., Pankiewicz, U., 2012. Changes of dehydroascorbic acid content in relation to total content of vitamin $C$ in selected fruits and vegetables. Acta Scientiarum Polonorum, Hortorum Cultus 11(6), 169-177

Murthy, Z.V.P., Joshi, D., 2007. Fluidized bed drying of Aonla (Emblica officinalis). Drying Technology 25, 883-889.

Panse, V.G., Sukhatme, P.V., 1985. Statistical Methods for Agricultural Workers, edn 4. ICAR, New Delhi.

Pathak, P.K., Preeti, D., Kumar, S., 2009. Effect of post-harvest treatments on shelf-life of aonla (Emblica officinalis) fruits damaged during harvesting. Journal of Food Science and Technology 46, 283-285.

Pathak, R.K., 2001. Aonla. In: Handbook of Horticulture. ICAR, New Delhi, 115-118.

Singh, S., Singh, A.K., Joshi, H.K., Bagle, B.G., Dhandar, D.G., 2009. Evaluation of packages for transportation and storability of aonla (Emblica officinalis) under semi-arid environment of Western India. Journal of Food Science and Technology 46, 127-131.

Singh, G., 2012. Checklist of Commercial Varieties of Fruits. $1^{\text {st }}$ (Ed.), New Delhi: Department of Agriculture and Cooperation.

Singh, J.K., Prasad, J., Singh, H.K., Singh, A., 2008. Effect of micro-nutrients and plant growth regulators on plant growth and fruit drop in aonla (Emblica officinalis Gaertn.) fruits cv.'Narendra Aonla-10'. Plant Archives 8, 911-13.

Tandon, D.K., Kumar, S., Dixit, A., Yadav, R.C., Sood, S., 2003. Processing potential of aonla. Paper presented at the National Seminar on Problems, Prospects and Utilization of aonla, Salem, Tamil Nadu, 8-10 ${ }^{\text {th }}$ July, 2003

Tarula, H., Rawat, J.M.S., Singh, K.K., Rawat, V., Singh, V., 2015. Effect of post-harvest treatments on quality and shelf life of aonla cultivars. HortFlora Research Spectrum 4(1), 17-21. 